\title{
Congenital malformations in newborns of alcoholic mothers
}

\author{
Malformações congênitas em recém-nascidos de gestantes consumidoras de álcool
}

\author{
Maria dos Anjos Mesquita ${ }^{1}$, Conceição Aparecida de Mattos Segre ${ }^{2}$
}

\begin{abstract}
Objective: To identify the presence of fetal alcohol syndrome, other alcohol-related congenital defects, and/or neurodevelopment disorders in newborns of mothers who consumed alcohol during gestation. Methods: In a public maternity in the city of São Paulo, 1,964 puerperal women were interviewed and 654 had consumed alcohol at some point during gestation. The newborns were clinically and laboratorially examined in order to identify the occurrence of fetal alcohol syndrome, congenital defects or neurodevelopment disorders related to alcohol. Results: Three children were found with fetal alcohol syndrome (1.5/1,000 live births), 6 with congenital defects related to alcohol (3.0/1,000 live births), and 67 with developmental disorders related to alcohol (34.1/1,000 live births). The congenital malformations found in these children were thin or absent corpus callosum, brain cyst, asymmetry of the cerebral ventricles, meningomyelocele, cleft lip, anteverted nose, low-set ears, megaureter, hydronephrosis, polydactyly, congenital clubfoot, aphalangia of the toes, cryptorchidism, and hypospadia. Conclusion: Newborns of mothers who consumed alcohol may have congenital malformations of various organs and systems, and early diagnosis is fundamental for a probable and occasional more effective resolution and progress.
\end{abstract}

Keywords: Infant, Newborn; Alcoholism; Fetal alcohol syndrome; Alcohol-related disorders; Congenital abnormalities

\section{RESUMO}

Objetivo: Identificar em recém-nascidos de mães consumidoras de álcool durante a gestação a presença da síndrome alcoólica fetal, outros defeitos congênitos relacionados ao álcool e/ou desordens de neurodesenvolvimento. Métodos: Em maternidade pública da cidade de São Paulo, foram entrevistadas 1.964 puérperas, das quais 654 consumiram álcool em algum momento da gestação. Os seus recémnascidos foram examinados clínica e laboratorialmente para identificar a ocorrência de síndrome alcoólica fetal, de defeitos congênitos ou ainda de desordens de neurodesenvolvimento relacionados ao álcool. Resultados: Foram encontradas 3 crianças com síndrome alcoólica fetal (1,5/1.000 nascidos vivos), 6 com defeitos congênitos relacionados ao álcool (3,0/1.000 nascidos vivos) e 67 com desordens de desenvolvimento relacionadas ao álcool $(34,1 / 1.000$ nascidos vivos). As malformações congênitas encontradas nessas crianças foram: corpo caloso fino ou ausente, cisto cerebral, assimetria dos ventrículos cerebrais, meningomielocele, lábio leporino, nariz antevertido, implantação baixa dos pavilhões auriculares, megaureter, hidronefrose, polidactilia, pé torto congênito, afalangia de artelho, criptorquidia e hipospádia. Conclusões: Os recém-nascidos de mães consumidoras de álcool podem apresentar malformações congênitas de diversos órgãos e sistemas, cujo diagnóstico precoce é fundamental para uma possível eventual resolução e evolução mais eficazes.

Descritores: Recém-nascido; Alcoolismo; Síndrome alcoólica fetal; Transtornos relacionados ao uso de álcool; Anormalidades congênitas

\section{INTRODUCTION}

The consumption of alcoholic beverages by a pregnant woman may cause in the fetus numerable deleterious effects $^{(1-9)}$, constituting a severe clinical picture called fetal alcohol syndrome (FAS), or a group of more subtle cognitive and/or behavioral dysfunctions ${ }^{(7,10)}$.

Currently, alcohol is considered the most common teratogenic agent, the principal cause of mental retardation and non-hereditarycongenitalabnormalities, with 91 anomalies already cataloged related to $\mathrm{FAS}^{(5-9)}$.

When the pregnant woman ingests alcohol, her baby also drinks it, meaning that during all gestation any dose of consumed alcohol may cause alterations in development ${ }^{(10)}$. To date, it is not known if there is a safe level of alcohol consumption, i.e., a limit under which no fetal damage would be caused ${ }^{(5)}$. The probability of the unborn child being affected and the severity of the syndrome are likely related to various factors, such as the dose consumed, pattern of consumption, the gestational

\footnotetext{
Study carried out at Hospital Municipal Maternidade-Escola de Vila Nova Cachoeirinha "Dr. Mário de Moraes Altenfelder Silva" - HMEVNC - São Paulo (SP), Brazil.

' MD; Neonatologist at Hospital Maternidade Cruz Azul and Hospital Maternidade Escola Vila Nova Cachoeirinha "Dr. Mário de Moraes Altenfelder Silva" - São Paulo (SP), Brazil.

2 PhD; Professor of the Specialization Course in Neonatology at Instituto Israelita de Ensino e Pesquisa Albert Einstein - IIEPAE, São Paulo (SP), Brazil.

Corresponding author: Maria dos Anjos Mesquita - Rua Marechal Hermes da Fonseca, 181, apto. 43 - Santana - CEP: 02020-000 - São Paulo (SP), Brazil - e-mail: manjosmesquita@uol.com.br

Received on: March 09, 2010 - Accepted on: Oct 04, 2010
} 
period when the fetus was exposed to alcohol, maternal and fetal alcohol metabolism, maternal health, and fetal genetic susceptibility ${ }^{(7,10)}$.

In 1996, the U.S. Institute of Medicine (IOM) of the National Academy of Sciences. in Washington, DC, with the intent of standardizing nomenclature related to the effects of alcohol on the newborn, introduced the terms: alcohol-related birth defects (ARBD), and alcohol-related neurodevelopmental disorders (ARND), describing conditions related to the maternal use of alcohol that are not found in the FAS ${ }^{(11)}$.

Today, for didactic purposes, physical, mental, behavioral and/or learning alterations have been grouped into the term "fetal alcohol spectrum disorders" (FASD) $)^{(1-9)}$ that covers FAS, ARBD, and ARND, the first of which is the most severe ${ }^{(1-3)}$.

Early identification and diagnosis of FASD is fundamental, with the purpose of affording health, education, and social services necessary to provide a better evolution of these children ${ }^{(1,12)}$.

FASD currently represents the greatest worldwide Public Health problem ${ }^{(13)}$; on the other hand, if the women abstains from consuming alcoholic beverages immediately before conception and throughout pregnancy, congenital anomalies related to alcohol are totally preventable ${ }^{(2,12,14-17)}$.

The Centers for Disease Control and Prevention (CDC), the National Task Force on Fetal Alcohol Syndrome, and the U.S. Surgeon General's Advisory recommend that pregnant women, those who desire to become pregnant, or even those who have a likelihood of becoming pregnant not ingest alcoholic beverages ${ }^{(3,17,18)}$. The same recommendation is made by the American Academy of Pediatrics, given that safe fetal alcoholemia is not known ${ }^{(19)}$. Since the worst damage of ethanol occurs during the embryogenesis phase, abstinence from alcohol is mandatory until before the diagnosis of pregnancy is confirmed ${ }^{(13,15,17-19)}$.

The FAS encompasses characteristic facial alterations, restriction of pre- or post-natal growth, and evidence of structural and/or functional modifications of the central nervous system (CNS), which are always associated with intrauterine exposure to alcohol ${ }^{(1,17)}$.

The ARBD comprise congenital anomalies including malformations and dysplasia ${ }^{(4)}$, and there can be structural cardiac, skeletal, renal, ocular, and pinna defects, among others ${ }^{(2)}$. The ARND present structural alterations of the CNS or behavioral or cognitive abnormalities which are inconsistent with the level of development, and are not explained by genetics or by familial and environmental antecedents ${ }^{(2)}$.

Analyzing the group of cases of FASD, it was noted that facial dysmorphia is often absent, since this finding is not obligatory, but there is the damage that the prenatal exposure to alcohol may provoke on cerebral function, which is permanent and incapacitating ${ }^{(4,20)}$.

\section{OBJECTIVE}

To identify in newborns of mothers who consume alcohol the presence of FAS, other congenital defects, and/or neurodevelopment disorders related to the maternal ingestion of alcohol.

\section{METHODS}

At the Hospital Municipal Maternidade-Escola de Vila Nova Cachoeirinha "Dr. Mário de Moraes Altenfelder Silva" (HMEVNC), located in the peripheral region of the city of São Paulo, an analytical cross-sectional observational study was conducted of live newborns and their mothers, during the period from August $13^{\text {th }}, 2006$ to January $21^{\text {st }}, 2008$.

During this time, 7,447 infants were born alive at the hospital, and 33 were admitted live after having been born out of the hospital. Operational motives of availability of one of the researchers (MAM) allowed the inclusion in the study of all newborns admitted between $00 \mathrm{~h} 01 \mathrm{~min}$ am on Sunday and $11 \mathrm{~h} 59 \mathrm{~min} \mathrm{pm}$ on Monday, in the referred period.

Newborns with genetic syndrome who died before the physical examination or who were discharged from hospital before the physical examination and/or maternal interview were excluded. The same was true for those transferred to another hospital before the physical examination, those whose mothers died before the interview, those who were not the first twin, and the infants of puerperal women who refused to participate in the study. The final sample was made up of 1,964 mother-newborn binomials.

The interview with the mothers of these children was structured with direct questions and closed-ended questions applied by one of the researchers (MAM). The $\mathrm{T}-\mathrm{ACE}^{(21)}$ questionnaire was also used in order to identify the consumers of alcoholic beverages. The infants were all examined by one of the researchers (MAM).

The variables collected from newborns were gestational age (GA), head circumference (HC), characteristics of the nasal philtrum, measurements of the palpebral fissure (PF) and of the largest width of the vermilion border of the upper lip (VBUL), as well as the presence of structural defects not related to other causes. The measurements of HC, PF, and of the largest width of the VBUL were performed between 24 and 72 hours of life so that subcutaneous edema and cranial alterations due to labor and delivery would not induce error.

The GA was estimated by the date of the last menstrual period (LMP) calculated according to the 
rule of Naegele, cited by Mongelli( ${ }^{(22)}$, by the New Ballard Score $(\mathrm{NBS})^{(23)}$ conducted between the $6^{\text {th }}$ and $48^{\text {th }}$ hours of life, or by the Capurro Somatic (CS) method ${ }^{(24)}$ performed during the first hour of life, whenever the infant's clinical condition did not allow the performance of the test by NBS. When the mother's date of LMP was unknown, the GA was determined by the NBS or CS methods.

According to the 2004 CDC criteria, facial alterations considered characteristic of FAS were PF $\leq$ $10^{\text {th }}$ percentile, smooth nasal philtrum, and thin VBUL. The restriction of growth was considered by the same agency when it corresponded to the birth weight (BW) and/or $\mathrm{HC}$ and/or length (L) $\leq 10^{\text {th }}$ percentile $^{(3)}$.

The infant's growth pattern and the measurements of PF and of the greatest width of VBUL of these children were evaluated using specific percentile curves based on measurements and GA in this population ${ }^{(25)}$ and were considered abnormal when less than or equal to the $10^{\text {th }}$ percentile for each GA.

The PF and the VBUL were determined with the newborn in dorsal decubitus, in a sleepy state or passively alert. The PF was assessed with the patient's eyes closed, due to the difficulty of neonates to open them. The greatest width of the VBUL was obtained with the upper and lower lips closed/sealed.

The presence or absence of a smooth nasal philtrum and of the anteverted nose was subjectively analyzed by the researcher who examined the children.

In the newborns of mothers who consumed alcohol, transfontanelle ultrasound was used when the presence of anatomical alterations of the skull and/or of the HC $\leq 10^{\text {th }}$ percentile were found, as per Usher's curve ${ }^{(26)}$ utilized as a guide.

Abdominal ultrasound and an X-ray of the chest and bones in infants were performed showing physical alterations in the thoracic, abdominal, and urogenital regions, and/or limbs.

The ultrasoundswere performed byultrasonographers at the institution. A cardiologist and a neurologist of the hospital assessed the newborns with cardiac and neurological abnormalities.

Based on 2004 CDC criteria, the newborns were considered as having FAS when there was a report of maternal consumption of alcohol during intrauterine life, characteristic facial alterations, growth restrictions, and structural and/or neurological alterations of the $\mathrm{CNS}^{(3)}$.

According to the criteria of IOM 1996, clarified by Hoyme et al., newborns were considered as having ARBD when there was a report of maternal consumption of alcohol during intrauterine life, two or more of the three characteristic facial alterations of FAS, and one or more congenital malformations ${ }^{(2)}$. By the same criteria, newborns were considered as having ARND when there was a report of maternal consumption of alcohol during intrauterine life, and structural and/or neurological alterations of the $\mathrm{CNS}^{(2)}$.

A $\mathrm{HC} \leq 10^{\text {th }}$ percentile and/or alterations on the ultrasound image of the brain were considered structural modifications of the CNS. Neurological alterations corresponded to the following data: convulsions/ seizures, tremors, irritability, alterations in suction/ swallowing not related to other causes. The other neurological criteria recommended by the American IOM were not considered, due to difficulty in evaluating them in neonates.

After the puerperal woman read and signed the informed consent form, drawn up for the specific purposes of this study, the participation of the patient and her child was allowed.

The Research Ethics Committee of the HMEVNC approved this study as per protocol number 009/2006.

\section{RESULTS}

Direct questions identified that $654(33.3 \%)$ of the total number of puerperal women analyzed in this population consumed alcohol at some moment during pregnancy. Of these, $140(21.4 \%)$ consumed it during all three trimesters of pregnancy, $159(24.3 \%)$ in two trimesters, and $355(54.3 \%)$ in one trimester.

The T-ACE questionnaire ${ }^{(21)}$ applied to the 1,964 pregnant women was positive in 611 , or $31.1 \%$ of the total number of puerperal women analyzed in this population, and one patient was unable to answer this questionnaire.

Table 1 displays the results that allowed a classification of newborns as to GA, according to weight at birth, HC, L, PF, and VBUL. Comparing the results of newborn variables with those of puerperal women as to alcohol consumption allowed the diagnosis of FAS in three newborns $(1.5 / 1,000$ live births), the identification of ARBD in 6 newborns

Table 1. Classification of newborns according to birth weight, head circumference, length, palpebral fissure and vermillion border of the upper lip in relation to gestational age

\begin{tabular}{llllll}
\hline Characteristics & & SGA & AGA & LGA & Total \\
\hline Birth weight & $\mathrm{n}$ & 194 & 1587 & 183 & 1964 \\
& $\%$ & 9.88 & 80.80 & 9.32 & 100.00 \\
Head circumference & $\mathrm{n}$ & 177 & 1614 & 173 & 1964 \\
& $\%$ & 9.01 & 82.18 & 8.81 & 100.00 \\
Length & $\mathrm{n}$ & 203 & 1632 & 129 & 1964 \\
& $\%$ & 10.34 & 83.09 & 6.57 & 100.00 \\
Palpebral fissure & $\mathrm{n}$ & 148 & 1643 & 173 & 1964 \\
& $\%$ & 7.53 & 83.66 & 8.81 & 100.00 \\
Vermillion border of the & $\mathrm{n}$ & 282 & 1484 & 198 & 1964 \\
upper lip & $\%$ & 14.36 & 75.56 & 10.08 & 100.00 \\
\hline
\end{tabular}

SGA: small for gestational age; AGA: appropriate for gestational age; LGA: large for gestational age 
(3.1/1,000 live births), and the diagnosis of ARND in 67 newborns (34.1/1,000 live births).

In this project, in newborns with a diagnosis of FAS, ARBD and ARND, the abnormalities related to the CNS appeared five times; those related to genitourinary system appeared six times, and to the osteoarticular system, five times. Cleft lip was present once, low-set ears in another case, and anteverted nose in 20 cases (Table 2).

Table 2. Congenital malformations of the studied children

\begin{tabular}{lc}
\hline Type of congenital malformation & How often it was identified \\
\hline Meningomyelocele & 1 \\
Agenesis of the corpus callosum & 1 \\
Thin corpus callosum & 1 \\
Brain cyst & 1 \\
Asymmetry of cerebral ventricles & 1 \\
Low-set ears & 2 \\
Cleft lip & 1 \\
Anteverted nose & 20 \\
Megaureter & 1 \\
Hydronephrosis & 1 \\
Cryptorchidism & 3 \\
Hypospadia & 1 \\
Polydactyly & 3 \\
Congenital club foot & 1 \\
Aphalangia of the toes & 1 \\
\hline
\end{tabular}

One of the children had FAS with a thin corpus callosum and low-set ears; another one had agenesis of the corpus callosum, megaureter, and hydronephrosis. In children with ARBD, cleft lip was identified in one, polydactyly in two, congenital club foot in one, and cryptorchidism in two. In infants with ARND, the existence of meningomyelocele was noted in one, brain cyst, asymmetry of cerebral ventricles, and lowset ears in one, aphalangia of the toe, hypospadia, and cryptorchidism in one, and polydactyly in another.

\section{DISCUSSION}

Alcohol consumption by pregnant women is without a doubt a serious worldwide Public Health concern, since it damages the fetus not only physically, but also in terms of behavior ${ }^{(1-3,5-7,10,27)}$.

Despite the known adversity of prenatal exposure to alcohol, the children that suffer the most are often not identified since the diagnosis of a newborn with FASD is difficult in most cases ${ }^{(28)}$. Clinical findings of FASD may go unnoticed, since they result from the combination of various factors that act at different critical periods of fetal development ${ }^{(1,2,11)}$. Thus, calling attention to the different aspects of FASD will contribute towards its early identification ${ }^{(29)}$.
Worldwide average prevalence of FAS is $0.5-2 / 1,000$ live births ${ }^{(3,9)}$. It is estimated that for each child with FAS there are three who do not present all the characteristics of the syndrome, but who have neurobehavioral deficits resulting from prenatal exposure to alcohol ${ }^{(17)}$. In the present study, the occurrence of FAS remained similar to that of literature, but the prevalence of the incomplete form of the syndrome, represented by ARBD and by ARND, was greater than expected, as per the CDC criteria ${ }^{(3)}$. It was also higher than the data found in a state-owned organization of São Paulo (SP), which showed a prevalence of the partial syndrome in 19.7/1,000 analyzed children ${ }^{(30)}$.

A plausible explanation for this finding is not easy. The specific pathophysiology of alcohol in fetus is still unknown ${ }^{(11,31,32)}$, but there is probably no one single mechanism that can explain all the damaging effects on the unborn child ${ }^{(6)}$. There are no markers capable of determining the specific action of alcohol on the fetus, nor the precise influence of the dose on the mechanism of developing of the syndrome ${ }^{(8)}$. It is a known fact that alcohol passes through the fetal barrier between the blood and the brain, and its effects on cerebral development are extremely complex ${ }^{(14,32)}$. In certain groups of cerebral cells it can lead to death, and in others, it interferes with the functions ${ }^{(32)}$. In this way, it can be suggested that some of these different factors may be acting in a specific manner according to characteristics of the population of the present study.

It is a well-known fact that exposure to alcohol at any time during pregnancy may cause effects on the CNS, which will be more damaging if they occur in the first five weeks of gestation ${ }^{(5,11,18)}$. One evident result is the decrease in cerebral growth, manifested by microcephalus and microencephaly ${ }^{(14)}$, but occasionally, prenatal exposure to alcohol can cause more specific brain lesions ${ }^{(5)}$. Habitually, however, brain damage is generalized and non-specific, with an increase in the appearance of functional abnormalities throughout the child's development ${ }^{(3)}$, which may present structural alterations of the CNS consistent with FAS, with no detectable functional deficit ${ }^{(1,3)}$. In the same way, mental retardation in the syndrome is not necessarily associated with cerebral malformations ${ }^{(20,33)}$.

In the present study, besides typical facial characteristics and intrauterine growth restriction, other facial anomalies were also noted, in addition to various malformations related to the nervous, osteoarticular, urinary and genital systems.

The typical facial characteristics of the action of alcohol on the unborn child may be associated with a narrow forehead, hemifacial hypoplasia, hypotelorism, hypertelorism, maxillary and mandibular hypoplasia, epicanthal fold, small and anteverted nose, wide and 
lowered nasal bridge, ogival palate, uvula aplasia, enamel hypoplasia, small teeth, dental malocclusions, cleft lip and/or cleft palate, micrognathia, and malpositioned and malformed prominent ears ${ }^{(4,8,20)}$. Some of these characteristics were also found in the newborns of the present study, and the frequency of anteverted nose was noteworthy.

Agenesis of the corpus callosum is described as one of the most frequent anomalies of the $\mathrm{CNS}^{(34)}$. This absence leads to conditions that vary from the inexistence of symptoms to various degrees of mental deficiency, convulsions/seizure and motor deficits ${ }^{(8)}$. The corpus callosum may also have a smaller size ${ }^{(33)}$, and both agenesis and decreased size of the corpus callosum were noted in some of the studied infants.

Hydrocephalus, meningomyelocele, decreased size of the cerebellum, of basal ganglia, and of the diencephalon may also be present in children of pregnant women who consumed alcohol during pregnancy ${ }^{(20,33)}$. In the present study meningomyelocele, brain cysts and asymmetry of cerebral ventricles were found.

In the ocular region, intrauterine exposure to alcohol may lead to palpebral ptosis, microphthalmia, coloboma, epicanthal folds, nystagmus, strabismus, and myopia $^{(8,20)}$. The optic nerve is often hypoplastic, and the retinal arteries are sinuous ${ }^{(13)}$. Vestibular disorders of the ear are also seen, with neurosensory hearing deficits and episodes of secretory otitis media ${ }^{(8)}$. Some of these anomalies were found in the children of this study.

Cardiac malformations may include defects of the ventricular and atrial septums ${ }^{(8,20)}$. Atrioventricular defects, patent arterial canal, and tetralogy of Fallot have been associated with $\mathrm{FAS}^{(35)}$. In the present study, no cardiopathy was identified in children.

Renal alterations associated with FAS include pyelonephritis, hematuria, renal failure, renal hypoplasia, and hydronephrosis ${ }^{(8)}$. In the present study, megaureter and hydronephrosis were identified.

Proximal radioulnar synostosis, valgus femur, bone fusion anomalies, scoliosis, and complex malformations of the cervical vertebrae, ribs, and fourth and fifth metacarpalbones, pectus excavatum, and joint alterations with luxations may occur ${ }^{(8)}$. In this study we found polydactyly, aphalangia, and congenital club foot.

Patients with FAS may have malformations of the external genitals such as hypoplasia of the labia minora and labia majora, increased penis or clitoris, and hypospadia ${ }^{(8,20)}$. Among the children of this study we identified cryptorchidism and hypospadia.

The limitations of this study include the fact that the children were examined by only one of the researchers, which could lead to an assessment error. Nevertheless, the care taken to adopt criteria based on intrauterine growth, size of the PF and VBUL constructed for the specific population may have compensated for this aspect. On the other hand, the examination of children only during the neonatal period and the lack of follow-up could underestimate the occurrence of other developmental problems that would appear at a later date.

The findings of this study, however, indisputably showed the presence of congenital anomalies and of possible functional deficits related to the consumption of alcohol by the mothers of these infants. The large consumption of alcoholic beverages by the pregnant women of this population make it necessary to investigate the issue starting in the prenatal phase, calling attention to the negative effects on the fetus.

We sound an alert, therefore, for investigation of the effects of alcohol on the infants of women who consume alcoholic beverages to become mandatory and for all healthcare professionals to identify these children with the purpose of making the diagnosis of FASD, enabling early intervention for a possible reduction of the consequences, albeit the cure is not possible.

\section{CONCLUSION}

The occurrence of FAS in the present study proved to be identical to that of literature, while that of ARBD and ARND was greater.

The suspicions of its existence and its identification are possible in neonates, allowing early and fundamental action, necessary for a more adequate evolution of these patients.

\section{REFERENCES}

1. Bertrand J, Floyd RL, Weber MK, Fetal Alcohol Syndrome Prevention Team, Division of Birth Defects and Developmental Disabilities, National Center on Birth Defects and Developmental Disabilities, Centers for Disease Control and Prevention (CDC). Guidelines for identifying and referring persons with fetal alcohol syndrome. MMWR Recomm Rep. 2005;54(RR-11):1-14.

2. Hoyme HE, May PA, Kalberg WO, Kodituwakku P, Gossage JP, Trujillo PM, et al. A practical clinical approach to diagnosis of fetal alcohol spectrum disorders: clarification of the 1996 institute of medicine criteria. Pediatrics. 2005;115(1):39-47.

3. National Center on Birth Defects and Developmental Disabilities. Centers for Control and Prevention. Department of Health and Human Services. National Task Force on Fetal Alcohol Syndrome and Fetal Alcohol Effect. Fetal alcohol syndrome: guidelines for referral and diagnosis. [Internet]. 2004 [cited 2008 Mar 8]. Available from: http://www.cdc.gov/ncbddd/fasd/documents/FAS guidelines_accessible.pdf

4. Chudley AE, Conry J, Cook JL, Loock C, Rosales T, LeBlanc N; Public Health Agency of Canada's National Advisory Committee on Fetal Alcohol Spectrum Disorder. Fetal alcohol spectrum disorder: Canadian guidelines for diagnosis. CMAJ. 2005;172(5 Suppl):S1-w21.

5. Eustace LW, Kang DH, Coombs D. Fetal alcohol syndrome: a growing concern for health care professionals. J Obstet Gynecol Neonatal Nurs. 2003;32(2):21521. Review. 
6. National Organization of Fetal Alcohol Syndrome. What is fetal alcohol syndrome? [Internet]. 2010 [cited 2010 Apr 11]. Available from: http://www. nofas.org/faqs. aspx?id =16

7. Mattson SN, Schoenfeld AM, Riley EP. Teratogenic effects of alcohol on brain and behavior. Alcohol Res Health. 2001;25(3):185-91. Review.

8. Núcleo Einstein de álcool e drogas (NEAD). Síndrome alcoólica fetal [Internet]. 2003 [acesso em 2010 Fev. 4]. Disponível em: http://apps.einstein.br/ alcooledrogas/novosite/complicacoes_gravidez_sindrome.htm

9. May PA, Gossage JP. Estimating the prevalence of fetal alcohol syndrome. A summary. Alcohol Res Health. 2001;25(3):159-67.

10. Grinfeld H, Segre CAM, Chadi G, Goldenberg S. 0 alcoolismo na gravidez e os efeitos na prole. Rev Paul Pediatr. 2000;18(1):41-9.

11. Thackray H, Tifft C. Fetal alcohol syndrome. Pediatr Rev. 2001;22(2):47-55.

12. Floyd RL, O'Connor MJ, Sokol RJ, Bertrand J, Cordero JF. Recognition and prevention of fetal alcohol syndrome. Obstet Gynecol. 2005;106(5 Pt 1):1059-64.

13. Riley EP, Guerri C, Calhoun F, Charness ME, Foroud TM, Li TK, et al. Prenatal alcohol exposure: advancing knowledge through international collaborations. Alcohol Clin Exp Res. 2003;27(1):118-35.

14. Jones MW, Bass WT. Fetal alcohol syndrome. Neonatal Netw. 2003;22(3):63-70.

15. Jacobs EA, Copperman SM, Joffe A, Kulig J, McDonald CA, Rogers PD, et al. Fetal alcohol syndrome and alcohol-related neurodevelopmental disorders. Pediatrics. 2000;106(2):358-61.

16. Cook JD. Biochemical markers of alcohol use in pregnant woman. Clin Biochem. 2003;36(1):9-19.

17. U.S. Surgeon General Advisory on alcohol use in pregnancy. Washington, DC: U.S. Department of Health and Human Services [Internet]. 2005 [cited 2010 Feb 2]. Available from: http://www.surgeongeneral.gov/pressreleases/ sg02222005.html

18. Weber MK, Floyd RL, Riley EP, Snider DE Jr. National Task Force on Fetal Alcohol Syndrome and Fetal Alcohol Effect. MMWR Recomm Rep. 2002;51 (RR-14);9-12.

19. American Academy of Pediatrics. Committee on Substance Abuse and Committee on Children With Disabilities. Fetal alcohol syndrome and alcoholrelated neurodevelopmental disorders. Pediatrics.2000;106(2 Pt 1):358-61.

20. Jones KL. Fetal alcohol syndrome. In: Jones KL, editor. Smith's Recognizable patterns of human malformation. Philadelphia: WB Saunders Company; 1997. p. 555-8.

21. Sokol RJ, Martier SS, Ager JW. The T-ACE questions: practical prenatal detection of risk-drinking. Am J Obstet Gynecol.1989;160(4):863-8.
22. Montenegro CAB, Rezende Filho J. Obstetrícia fundamental. 11. ed. Rio de Janeiro: Guanabara Koogan; 2008.

23. Capurro H, Konichezky S, Fonseca D, Caldeyro-Barcia R. A simplified method for diagnosis of gestacional age in the newborn infant. $J$ Pediatr. 1978;93(1):120-2.

24. Ballard JL, Khoury JC, Wedig K, Wang L, Eilerrs-Walsman BL, Lipp R. New Ballard Score, expanded to include extremely premature infants. J Pediatr. 1991;119(3):417-23.

25. Mesquita MA, Segre CA. Frequiência dos efeitos do álcool no feto e padrão de consumo de bebidas alcoólicas pelas gestantes de maternidade pública da cidade de São Paulo. Rev Bras Crescimento Desenvolv Hum. 2009;19(1):63-77.

26. Usher R, McLean F. Intrauterine growth of live-born Caucasian infants at sea level: standards obtained from measurements in 7 dimensions of infants born between 25 and 44 weeks of gestation. J Pediatr. 1969;74(6):901-10.

27. Bearer CF. Markers to detect drinking during pregnancy. National Institute on Alcohol Abuse an Alcoholism (NIAAA) [Internet]. 2001 [cited 2010 Fev 11]. Available from: http://www.niaaa.nih.gov/publications/arh25-3/210218.htm

28. Stoler JM, Holmes LB. Recognition of facial features of fetal alcohol syndrome in the newborn. Am J Med Genet C Semin Med Genet. 2004;127C(1):21-7.

29. Astley SJ, Clarren SK. Diagnosing the full spectrum of fetal alcohol-exposed individuals: introducing the 4-digit diagnostic code. Alcohol Alcohol. 2000;35(4):400-10.

30. Cardilli J. Síndrome fetal alcoólica tem altas taxas na população de baixa renda [Internet]. 2006 [citado 2010 Fev 11]. Disponível em: http://www.usp. br/agen/repgs/2006/pags/053.htm

31. Moraes CL, Reichenheim ME. Rastreamento de uso de álcool por gestantes de serviços públicos de saúde do Rio de Janeiro. Rev Saúde Pública. 2007:41(5):695-703.

32. Goodlett CR, Horn KH. Mechanisms of alcohol-induced damage to the developing nervous system. Alcohol Res Health. 2001;25(3):175-84.

33. Mattson SN, Riley EP, Sowell ER, Jernigan TL, Sobel DF, Jones KL. A decrease in the size of the basal ganglia in children with fetal alcohol syndrome. Alcohol Clin Exp Res. 1996;20(6):1088-93.

34. Roebuck-Spencer TM, Mattson SN, Marion SD, Brown WS, Riley EP. Bimanual coordination in alcohol-exposed children: role of the corpus callosum. J Int Neuropsychol Soc. 2004;10(4):536-48.

35. Löser H, Pfefferkorn JR, Themann H. Alcohol in pregnancy and fetal heart damage [abstract]. Klin Padiatr. 1992;204(5):355-9. 